\title{
PENGARUH LAYANAN BIMBINGAN KELOMPOK DENGAN TEKNIK ROLE PLAYING TERHADAP SELF AWARNEES SISWA KELAS XI IPA 3 SMAN 9 KOTA BENGKULU
}

\author{
Rita Fitriyani ${ }^{1}$, Dodo Sutardi ${ }^{2}$, Widya Kartika Sari ${ }^{3}$ \\ ${ }^{1,2,3}$ Prodi Bimbingan Dan Konseling Universitas Prof. Dr Hazairin, S.H \\ e-mail \\ ritafitriyanibkunihaz@gmail.com
}

\begin{abstract}
The research purpose to find out: 1. self awareness of students who are given services group guidance using role playing techniques. 2. self awareness of students who are given group guidance services without using role playing techniques. 3 differences in self awareness of students who are given group guidance services with role playing techniques and without using role playing techniques.

The method used in this research is the experimental method. The population in the study were all students of class XI IPA 3 SMAN 9 bengkulu city. The sample is determined by random technique with the number of 20 students in class XI IPA 3. Technique data analysis that is used is descriptive percentage and test that processing using program SPSS 20.

After the data collected and analyzed obtained the following research results:

1. The level of self awareness of students who are given group guidance services without the use of role playing techniques are generally at a moderate level.

2. The level of self awareness of students in the experimental group who were given group counseling services using role playing techniques were generally at a high level.

3. There is a significant difference between group counseling services with role playing techniques and without using role playing technique to self awareness of students of grade XI IPA 3 SMAN 9 bengkulu city. Then the treatment provided significant effect.
\end{abstract}

Keywords: group guidance, role playing technique, self awareness.

\begin{abstract}
Abstrak
Tujuan penelitian untuk mengetahui: 1. kesadaran diri siswa yang diberi bimbingan kelompok layanan menggunakan teknik bermain peran. 2. kesadaran diri siswa yang diberikan layanan bimbingan kelompok tanpa menggunakan teknik bermain peran. 3 perbedaan dalam kesadaran diri siswa yang diberikan layanan bimbingan kelompok dengan teknik bermain peran dan tanpa menggunakan teknik bermain peran.

Metode yang digunakan dalam penelitian ini adalah metode eksperimen. Populasi dalam penelitian ini adalah semua siswa kelas XI IPA 3 SMAN 9 kota bengkulu. Sampel ditentukan dengan teknik acak dengan jumlah 20 siswa di kelas XI IPA 3. Teknik analisis data yang digunakan adalah persentase deskriptif dan uji t yang mengolah menggunakan program SPSS 20.

Setelah data terkumpul dan dianalisis diperoleh hasil penelitian berikut:

1. Tingkat kesadaran diri siswa yang diberi layanan bimbingan kelompok tanpa menggunakan teknik bermain peran pada umumnya berada pada tingkat sedang.

2. Tingkat kesadaran diri siswa dalam kelompok eksperimen yang diberi layanan konseling kelompok menggunakan teknik bermain peran pada umumnya berada pada tingkat tinggi.

3. Ada perbedaan yang signifikan antara layanan konseling kelompok dengan teknik bermain peran dan tanpa menggunakan teknik bermain peran untuk kesadaran diri siswa kelas XI IPA 3 SMAN 9 kota bengkulu. Kemudian pengobatan memberikan efek yang signifikan.
\end{abstract}

Kata kunci: bimbingan kelompok, teknik bermain peran, kesadaran diri. 


\section{PENDAHULUAN}

Individu memiliki awareness terhadap diri sendiri dan lingkungan sekitarnya, baik awareness dalam menerima keadaan diri atau memahami potensi diri. Hal ini sesuai yang dijelaskan oleh Golamen (dalam Maharani dan Mustika, 2016) Self awareness merupakan kesadaran seseorang yang mampu memahami, menerima dan mengelola seluruh potensi untuk mengembangkan hidup dimasa depan dengan wawasan keadaan atau wawasan mengenai alasan-alasan dari tingkah laku atau pemahaman diri sendiri.

Self awareness yang tinggi mendorong seseorang untuk mampu akan menerima kenyataan hidupnya (Bril dalam Dariyo, 2016: 262), sebab ia dapat mengenali potensi dan kekuatan maupun kelemahan dalam dirinya (Thomasson dalam Dariyo, 2016: 268) dalam hal ini akan berpengaruh pada bagaimana individu tersebut dapat menjalankan perannya sebagai siswa, Baik kesadaran terhadap dirinya maupun lingkungannya. Sehingga self awareness ini sendiri bagi siswa dapat berfungsi sebagai kontrol untuk mengendalikan diri serta pengambilan keputusan untuk menjalankannya atau bertindak secara sadar. Dengan ciri-ciri bahwa siswa mempunyai kesadaran yang menjadi pedoman untuk nilai dan sasaran mereka, sadar ingin terus belajar dan mengembangkan diri serta mampu membuat keputusan yang baik kendati dalam keadaan yang tidak pasti.

Fenomena yang terjadi pada siswa kelas XI IPA 3 di SMAN 9 Kota Bengkulu, berdasarkan observasi dan wawancara kepada siswa dan guru Bimbingan dan Konseling pada tanggal 8 Februari 2018 Berdasarkan hasil tersebut terindikasi siswa yang memiliki self awareness rendah seperti kesadaran diri akan menghargai kemampuan yang dimiliki, rendahnya kesadaran terhadap makna belajar dengan memanfaatkan waktu hanya untuk bermainmain, serta selalu meremehkan tugas-tugas yang diberikan, mereka seakan membuat standar tersendiri yang sesuai dengan dirinya dan merasa nyaman ketika mereka melakukan kesalahan atau pelanggaran tersebut.

Berdasarkan paparan diatas penulis akan mengkaji tentang "Pengaruh Layanan Bimbingan Kelompok dengan Teknik Role Playing terhadap Self Awareness Siswa Kelas XI IPA 3 SMAN 9 Kota Bengkulu.

Masalah dalam penelitian ini adalah (1) Bagaimana tingkat Self awareness siswa yang diberi layanan bimbingan kelompok menggunakan teknik role playing, (2) 
Bagaimana tingkat Self awareness siswa yang diberi layanan bimbingan kelompok tanpa menggunakan teknik role playing, (3) Apakah terdapat perbedaan self awareness siswa yang diberi layanan bimbingan kelompok dengan tehnik role playing dan tanpa menggunakan teknik role playing ? dengan tujuan yang akan dicapai (1) Untuk mengetahui tingkat Self awareness siswa yang diberi layanan bimbingan kelompok menggunakan teknik role playing, (2) Untuk mengetahui tingkat Self awareness siswa yang diberi layanan bimbingan kelompok tanpa menggunakan teknik role playing, (3) Untuk mengetahui perbedaan self awareness siswa yang diberi layanan bimbingan kelompok dengan tehnik role playing dan tanpa menggunakan teknik role playing.

Penelitian ini bermanfaat bagi siswa dapat membantu manangani dan meningkatkan self awareness yang rendah. Bagi guru bimbingan dan konseling mampu dijadikan referensi dalam menangani kendala-kendala yang dialami siswa dengan memberikan layanan sesuai kebutuhan. Bagi sekolah penelitian ini dapat menambah memperkaya kajian bimbingan dan konseling yang dapat dijadikan pertimbangan dalam memningkatkan pelaksanaan bimbingan dan konseling diseloah.

\section{METODE}

Penelitian menggunakan pendekatan kuantatif dengan metode Quasi eksperimen, Model Non Equivalent Control Grup Design (Sugiyono, 2014: 79).

Desain ini adalah suatu rancangan penelitian yang terdiri dari dua kelompok yaitu kelompok eksperimen diberikan perlakuan dan kontrol yang tidak diberi perlakuan. Kelompok akan diberi tes (Pretest) dan diakhir (Post-test), untuk melihat perbedaan setelah diberi perlakuan atau Treatment pada kelompok eksperimen. populasi dalam penelitian ini adalah seluruh siswa kelas XI IPA 3 SMAN 9 Kota Bengkulu.

Pengambilan sampel dilakukan deng an teknik Random dengan cara undian yaitu dengan mengelompokkan siswa menjadi 3 bagian (A, B, dan C). Siswa diminta mengambil nomor undian dengan $\mathrm{A}$ (siswa masuk kelokpok ekasperimen), B (siswa masuk dalam kelompok kontrol) dan C (sisiwa tidak termasuk sampel). Berdasarkan teori bimbingan kelompok bahwa jumlah anggota kelompok sebanyak 8-10 orang (Prayitno, 2004). Maka sampel dalam penelitian ini terdiri dari 20 siswa, 10 siswa kelompok eksperimen (A) dan 10 siswa kelompok kontrol (B). 


\section{HASIL PENELITIAN}

Penelitian ini menghasilkan data kuantitatif yang disajikan dalam bentuk tabel dan menganalisis hasil data tentang tingkat self awarenees untuk melihat pengaruh yang terjadi menggunakan program SPSS 20. Diperoleh hasil tingkat self awareness siswa seperti pada tabel di bawah ini :

Tabel 1. Presentase tingkat self awareness kelompok eksperimen

\begin{tabular}{|l|c|c|}
\hline \multicolumn{1}{|c|}{ Tingkat } & Frekuensi & Presentase \\
\hline Sangat tinggi & 0 & $0 \%$ \\
\hline Tinggi & 6 & $60 \%$ \\
\hline Sedang & 4 & $40 \%$ \\
\hline Rendah & 0 & $0 \%$ \\
\hline Sangat rendah & 0 & $0 \%$ \\
\hline Jumlah & 10 & $100 \%$ \\
\hline
\end{tabular}

Dari 10 siswa pada kelompok eksperimen yang memiliki tingkat self awareness sangat tinggi terdapat 0 siswa dengan besar presentase $0 \%$, kategori tinggi terdapat 4 siswa dengan presentase $40 \%$, kemudian kategori sedang terdapat 6 siswa dengan besar presentase $60 \%$, kategori rendah 0 siswa dengan besar presentase $0 \%$, dan kategori sangat rendah 0 siswa dengan besar presentase tingkat self awareness $0 \%$.

Tabel 2. Presentase tingkat self awareness kelompok kontrol

\begin{tabular}{|l|c|c|}
\hline Tingkat & Frekuensi & Presentase \\
\hline Sangat tinggi & 0 & $0 \%$ \\
\hline Tinggi & 2 & $20 \%$ \\
\hline Sedang & 8 & $80 \%$ \\
\hline Rendah & 0 & $0 \%$ \\
\hline Sangat rendah & 0 & $0 \%$ \\
\hline Jumlah & $\mathbf{1 0}$ & $\mathbf{1 0 0 \%}$ \\
\hline
\end{tabular}

Dari 10 siswa pada kelompok kontrol dengan tingkat self awareness sangat tinggi terdapat 0 siswa dengan tingkat presentase sebesar 0\%, kategori tinggi terdapat 2 siswa dengan besar presentase $20 \%$.

Selanjutnya kategori sedang terdapat 8 siswa dengan besar presentase $80 \%$, kemudian kategori rendah terdapat 0 siswa dengan besar presentase 0\% dan kategori sangat rendah terdapat 0 siswa dengan besar presentase tingkat self awareness $0 \%$.

Tabel 3. Two independent samples Test Statisticsa

\begin{tabular}{|c|c|}
\hline & Skor_Self_awareness \\
\hline $\begin{array}{c}\text { Asymp. Sig. (2- } \\
\text { tailed) }\end{array}$ &, 004 \\
\hline
\end{tabular}

Pengujian hipotesis dengan menggunakan analisis nonparametrik dengan menggunakan uji Nam-Whitney $U$ yaitu two-independent-samples-test dengan menggunakan aplikasi SPSS 20.

Berdasarkan penyajian data pada tabel 3. Uji hipotesis yang digunakan dalam perhitungan nilai skor hasil kelompok eksperimen dan kelompok kontrol. Hasil dari perhitungan SPSS 20 diperoleh nilai sig. (2-Tailed) 0.004, karena nilai sig. 0.004 $<$ a 0,05 maka terdapat adanya perbedaan. Sehingga jika terdapat perbedaan layanan 
bimbingan kelompok dengan teknik role playing dan tanpa menggunakan teknik role playing terhadap self awareness siswa kelas XI IPA 3 SMAN 9 kota Bengkulu maka perlakuan yang diberikan berpengaruh.

\section{PEMBAHASAN}

\section{Tingkat self awareness kelompok control}

Kelompok kontrol diberi perlakuan layanan bimbingan kelompok dengan materi yang sama pada perlakuan kelompok eksperimen (lampiran 3) tetapi tanpa menggunakan teknik role playing. Berdasarkan tabel 4.1 diperoleh hasil siswa dengan tingkat sedang terdapat 8 siswa dan tingkat tinggi terdapat 2 siswa. Layanan bimbingan kelompok yang dilaksanakan dapat mempengaruhi self awarness siswa meskipun dalam tingkatan sedang. Layanan yang diberikan tanpa menggunakan teknik hanya pada tingkatan sedang dikarenakan dalam proses pemberian layanan bimbingan kelompok kemungkinan banyak variabel lain yang dapat mepengaruhi, misalnya dalam kegiatan layanan Bimbingan Kelompok siswa cenderung Pasif, kurang antusias, kurang terbuka dalam membahas topik bimbingan kelompok sehingga anggota tidak (berfikir, merasa, bersikap,bertindak dan bertanggungjawab) ber BMB3 dengan baik. Sesuai dengan penjelasan menurut Prayitno (2012: 161) bahwa suatu kelompok tidak lempas dari peran anggota kelompok, yaitu anggota kelompok mampu (berfikir, merasa, bersikap,bertindak dan bertanggungjawab) BMB3.

\section{Tingkat self awareness kelompok eksperimen}

Kelompok eksperimen diberi perlakuan layanan bimbingan kelompok dengan materi yang sama pada perlakuan kelompok kontrol (lampiran 3) tetapi menggunakan teknik role playing. Berdasarkan tabel 4.2 diperoleh hasil siswa dengan tingkat sedang terdapat 4 siswa dan tingkat tinggi terdapat 6 siswa, sehingga pada kelompok eksperimen pada umumnya adalah tinggi. Melalui layanan bimbingan kelompok menggunakan sebuah teknik yaitu role playing menjadi hal yang penting.karena penggunakan teknik dalam kegiatan dapat membuat suasana atau dinamika yang terbangun bergairah dan membuat siswa tidak cepat jenuh dalam menggikuti kegiatan. Terlihat siswa berpartisipasi aktif dan sangat antusias untuk 
mengikuti kegiatan dikarenakan kegiatan tersebut menggunakan teknik role playing.

Berdasarkan penjelasan Romlah (dalam Susilowati, 2015) teknik role playing adalah suatu alat belajar untuk meningkatkan ketrampilan dan pengertian mengenai hubungan antara manusia dengan jalan memerankan situasi-situasi yang paralel dengan apa yang terjadi dalam kehidupan sebenarnya. Teknik role playing ini sangat efektif untuk memfasilitasi siswa dalam mempelajari perilaku sosial dan nilainilai. Menurut Payitno (1995:178) bahwa kegiatan bimbingan kelompok akan mencapai tujuan-tujuan nya jika memanfaatkan dinamika atau ketika dinamika dengan baik terbangun dapat dikatakan kegiatan layanan bimbingan kelompok berhasil.

\section{Perbedaan self awareness kelompok kontrol dengan kelompok eksperimen}

Berdasarkan hasil tabel 3. uji twoIndependent Samples Test menunjukan terdapat perbedaan antara self awareness siswa yang diberi teknik role playing dan yang tidak diberi teknik melalui layanan bimbingan kelompok pada siswa kelas XI IPA 3 SMAN 9 kota Bengkulu. Hal tersebut terlihat dengan besarnya nilai (sig.2-tailed) $0.004<\mathrm{a}(0,05)$ yang menyatakan bahwa $\mathrm{H}_{\mathrm{O}}$ di tolak dan $\mathrm{H}_{\mathrm{a}}$ diterima.
$\mathrm{H}_{\mathrm{a}}$ diterima menunjukakn bahwa terdapat perbedaan yang signifikan terhadap teknik role plying melalui layanan bimbingan kelompok terhadap self awareness siswa. Perubahan yang ditandai dengan meningkatnya self awareness siswa juga mengidentifikasi bahwa teknik role playing yang digunakan dalam penelitian ini memiliki pengaruh terhadap tingkat self awareness siswa. Hal ini sesuai dengan tujuan dari teknik role playing menurut Uray Herlina (2015 : 10) Semakin banyak kesempatan pembelajaran untuk mengungkapkan diri terutama tentang kesadaran (self awareness) yang menjadi kendala siswa, sehingga siswa mampu mengungkapkan diri dengan dengan bermain untuk memecahkan masalah yang dihadapi.

Keberhasilan anggota kelompok dalam memaksinmalkan peran melalui teknik role playing tidak terlepas dari beberapa hal salah satunya yaitu menerapkan tahapan teknik role playing. Hal ini sesuai dengan penjelasan Hidayat, ZA dan Muhyidin (dalam Herlina, 2015) dari beberapa tahapan seperti pemeranan sesuai skenaryo dan kemudian adanya diskusi dan evaluasi akan membantu pelaksanaan teknik role playing akan efektif. Keefektifan pemberian layanan bimbingan 
kelompok dengan teknik role playing ini juga diperkuat dengan penelitian sebelumnya yang dilakukan oleh Susilowati dalam penelitiannya dengan judul "Efektifitas Bimbingan Kelompok Melalui Teknik Role Playing untuk Meningkatkan Self Awareness Peserta Didik" pada tahun 2015.

Berdasarkan analisis data terbukti bahwa terdapat perbedaan signifikan self awareness siswa yang diberi layanan bimbingan kelompok dengan teknik role playing dan tanpa menggunakan teknik role playing. Sehingga dapat disimpulkan bahwa ketika terdapat perbedaan yang signifikan antara layanan bimbingan kelompok dengan teknik role playing dan tanpa menggunakan teknik role playing, makaperlakuan yang diberikan berpengaruh secara signifikan (Sugiyono, 2014: 76).

\section{KESIMPULAN}

Berdasarkan pengumpulan data dan analisis data, maka dapat disimpulkan sebagai berikut :

1. Self awareness siswa yang di beri layanan bimbingan kelompok tanpa menggunakan teknik role playing pada umumnya berada pada tingkatan sedang.
2. Self awareness siswa pada kelompok eksperimen yang di beri layanan bimbingan kelompok menggunakan teknik role playing pada umumnya berada pada tingkatan Tinggi.

3. Terdapat perbedaan yang signifikan antara layanan bimbingan kelompok dengan teknik role playing dan tanpa menggunakan teknik role playing terhadap self awareness siswa kelas XI IPA 3 SMAN 9 Kota Bengkulu. Maka perlakuan yang diberikan berpengaruh secara signifikan.

\section{SARAN}

Berdasarkan hasil penelitian dan kesimpulan diatas maka disarankan kepada:

1. Bagi siswa untuk dapat meningkatkan self awareness sesuai dengan perannya sebagai siswa.

2. Bagi guru Bimbingan dan Konseling diharapkan mampu melaksanakan layanan bimbingan kelompok dengan teknik role playing untuk menangani siswa yang memiliki self awareness rendah sesuai dengan perannya sebagai siswa. perlu adanya pelaksanaan tindak lanjut layanan secara tuntas terkhusus layanan bimbingan kelompok.

3. Bagi pihak sekolah dimohon dapat dijadikan sebagai bahan acuan dan 
masukan dalam pelaksanaaan

Bimbingan dan Konseling di sekolah, serta pihak sekolah memaksimalkan bimbingan dan konseling dalam pemberian layanan kepada siswa terkhusus layanan bimbingan kelompok yang belum maksimal dilaksanakan.

\section{DAFTAR PUSTAKA}

Dariyo, A. 2016. Peran self awareness dan ego support terhadap kepuasaan hidup remaja tionghoa. Psikodimensia, 15 (2): 254-274.

Goleman, Daniel. 1996. Working With Emotional Intelegence, Kesadaran Emosi Untuk Mencapai Puncak Prestasi, Terjemah Alex Tri Kantjono Widodo, Jakarta: Garamesia Pustaka Utama.

Herlina, U. 2015. Teknik role playing dalam bimbingan kelompok. Jurnal Pendidikan Sosial. 02 (1): 1-14.

Maharani, L dan M. Mustika. 2016. Hubungan self awarenes dengan kedisiplinan perserta didik kelas VIII di SMP Wiyatama Bandar Lampung. Jurnal Bimbingan dan konseling, 03 (1): 17-31.

Prayitno. 1995. Layanan Bimbingan dan Konseling. Padang: Ghalia Indonesia.
Prayitno dan Amti, Erman. 2004. Seri Kegiatan Pendukung Konseling (LIL9). Padang. UNP.

Prayitno. 2012. Jenis Layanan dan Kegiatan Pendukung. Padang: Universitas Negri Padang.

Priyatno, Duwi. 2012. Cara Kilat Belajar Analisis Data dengan SPSS 20. Yogyakarta: Andi OFSET.

Solso, Robert. L. dkk. 2008. Psikologi Kognitif. Jakarta: Erlangga

Sugiyono. 2014. Metode Penelitian Kuantitatif, Kualitatif, dan $R \& D$. Bandung: Alfabet.

Sukardi, Dewa Ketut. 2002. Pendidikan konseling. Jakarta: Renika Cipta.

Susilowati. 2015. Efek tifitas bimbingan kelompok melalui layanan bimbingan kelompok untuk meningkatkan self awareness peserta didik. Jurnal Bimbingan dan Konseling Islam. 05 (2): 1-23.

Uno, B H. 2006. Orientasi Baru dalam Psikologi Pembelajaran. Jakarta: Bumi Aksara.

Wibowo, Mungin Edi. 2005. Konseling Kelompok Perkembangan. Semarang: UNNES Press. 